\title{
Enabling legislation in diagnosis and prescribing of medicine by nurses/health practitioners
}

\section{Geyer N, M.Cur, Democratic Nursing Organisation of South Africa}

\section{Abstract}

The South African health system has undergone major changes over the last $5-10$ years. These rapid changes have not only significantly increased the visibility of the nurse practitioner in South Africa, but are also posing challenges to the profession and health care services that need to be addressed.

In its Health Policies the Government has indicated that the nursing/midwifery profession, as the biggest group of health care professionals, should be the practitioners to provide primary health care services to the communities. But to do this, they require enabling legislation.

The "permit system" has been in place for non-pharmacists and institutions other than hospitals and pharmacies to acquire, possess, use and supply medication for a number of years. This system has been fraught with problems mainly due to a lack of clarity on exactly how the system works and the system has been abused.

The purpose of this article is to explore the current situation with the aim to analyze the legal framework that exists within which the primary health care services, and specifically the diagnosing and prescribing of medication, could be performed.

The conclusion is made that health legislation has not kept up with the rapid changes in service delivery and are not adequate to empower the nurse to deliver health services. Some recommendations are made for the way forward.

\section{Abstrak}

Die stelsel van gesondheidsorg in Suid Afrika het oor die laaste 5 - 10 jaar groot veranderinge ondergaan. Hierdie veranderinge het nie net die sigbaarheid van die verpleegkundige en vroedvrou in Suid Afrika verhoog nie, maar ook uitdagings aan die professie en die gesondheidsdienste gestel wat aangespreek moet word. In die Gesondheidsbeleid van die Regering word aangedui dat die beroep (verpleegkunidges en vroedvroue) as die grootste gesondheidsprofessie, die aangewese praktisyns is om primere gesondheidsorg aan die gemeenskap te voorsien. Om dit te kan doen, is instaatstellende wetgewing egter nodig.

Die permitstelsel maak voorsiening vir nie-aptekers en instansies wat nie hospitale of apteke is nie, om medikasie aan te skaf, te besit, aan te hou en uit te reik. Hierdie stelsel het baie probleme ondervind, hoofsaaklik as gevolg van onduidelikheid hoe die stelsel werk, en is misbruik. Die doel van hierdie artikel is om die situasie soos dit tans is te ondersoek met die doel om die wetlike raamwerk waarbinne die verpleegkundige en vroedvroue primere sorgdienste, en spesifiek diagnosering van siektes en voorskryf van medikasie, moet lewer, te ontleed.

Die gevolgtrekking word gemaak dat die wetgewing nie met die vinnige verandering in dienslewering tred gehou het nie, en dus nie toereikend is om die verpleegkundige en vroedvrou te bemagtig om gesondheidsdienste te lewer nie. Voorstelle word gemaak om hirdie probleem aan te spreek.

\section{Introduction}

The South African health system has undergone major changes over the last $5-10$ years. This includes the shift from a mainly curative, hospital-based service to a primary health care, community-based service. These changes also include the amalgamation of 14 different departments of health into one unified health service. These rapid changes have not only significantly increased the visibility of the nurse practitioner in South Africa, but are also posing challenges to the profession and health care services that need to be addressed.

In its Health Policies the Government has indicated that the nursing/midwifery profession, as the biggest group of health care professionals, should be the practitioners to provide primary health care services to the communities (Department of Health 1994:9; Pick, Nevhutalu, Cornwall \& Masuku 2001: iii). But to do this, they require facilities, sufficient and working equipment, adequate stock and above all, enabling legislation.

There is a concerning trend that nurses and midwives are exploited as a result of the disparities in the system and a lack of clarity on how the system works. They are forced to deliver the services without the required legislation or legal procedures in place, often without the necessary training to perform these services and in less than ideal circumstances where there is a lack of equipment and insufficient stock. If they refuse to do so, they are often threatened with disciplinary action or told to leave if they do not want to comply or do not like it. Should a nurse with specialized clinical skills training, however, move from the public sector to a private sector facility, all the legal determinations are applied and no nurse is allowed to do any diagnosing, treatment and prescribing. 


\section{Terminology}

The following terminology will be used in the article:

Diagnose - the identification of, and discriminating between physical, psychological and social signs and symptoms in man (South African Nursing Council, 1984).

Dispense - the evaluation of the prescription, making up and issuing of the prescription and counseling the client on taking the medication (Kluge 1998).

Permits - permits issued in terms of Section 22A(12) of the Medicines and Related Substances Act, Act 101 of 1965, as amended, to acquire, possess, use and supply medication under conditions determined by the Director-General: Health (South Africa, 1965).

Prescribe - giving written directions regarding those treating, nursing care, coordinating, collaborating and patient advocacy functions essential to the effective execution and management of the nursing regimen (South African Nursing Council, 1984). Prescribing treatment for a patient entails written directions for treatment which is dispensed by another practitioner (Kluge 1998).

Nursing regimen - the regulation of those matters which through nursing intervention have an influence on the pre- wise (South Africa, 1965).

\section{General rule}

The general rule with regard to medicines and based on the medicines control and health professional's Acts, is illustrated in figure 1 . This indicates that medical practitioners, dentists, veterinary surgeons and the allied health practitioners prescribe medication, pharmacists and some of the allied health practitioners prepare and dispense the script, nurses administer the medication and all practitioners evaluate the effect of the medication.

\section{Historical development of legislative needs}

Historically the need to amend legislation to enable health care practitioners to provide a comprehensive health service in South Africa arose during the 1970's. The establishment of the independent and self-governing states during the 1970's, resulted in a situation where the number of medical practitioners available in these areas were inadequate to provide health services. A special arrangement had to be made to enable registered nurses to perform these services (Pillay, 2000). During the same period the Soweto uprising necessitated the withdrawal of all white medical practitioners from the health services leaving only the registered nurses to run the services (Subedar, 2001).

\section{Figure 1: General rule regarding medication}

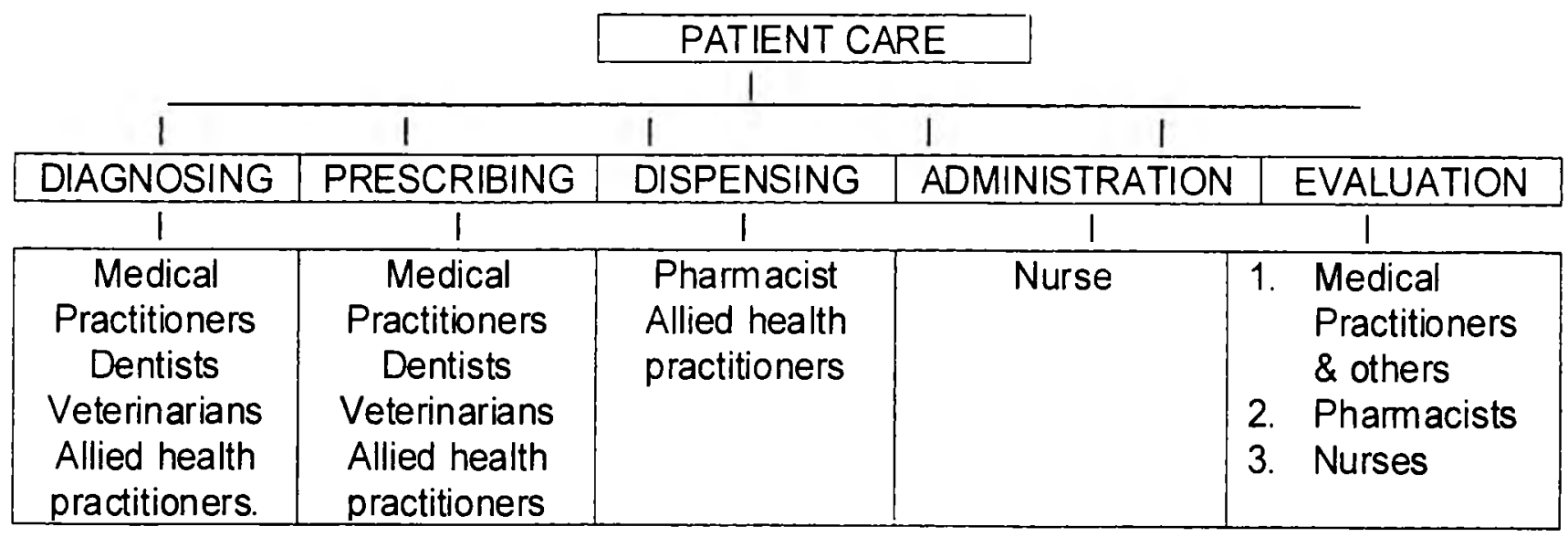

ventive, promotive, curative or rehabilitative aspects of health care and includes the provision of nursing care plans, their implementation and evaluation thereof and recording of the course of the health problem, the health care received by a patient and its outcome whilst a patient is in the charge of the nurse (South African Nursing Council, 1984).

Sell - sell by wholesale or retail and includes import, offer, advertise, keep, expose, transmit, consign, convey or deliver for sale or authorize, direct or allow a sale, prepare or possess for purposes of sale, and barter or exchange or supply or dispose of to any person whether for a consideration or other-
Both these situations required an amendment to the legislation to enable the nursing profession to deliver a comprehensive health service at clinic level. This need culminated in the amendment of the Nursing Act in 1985 by the promulgation of section 38A (South Africa, 1978).

Since 1994, developments in health care policy and the determination that the nurse practitioner will be the frontline health care practitioner, have made a further amendment to the legislative framework necessary (Department of Health 1994:9; Pick et al 2001: $51-61$ ). 


\section{Provision for special circumstances}

There are many circumstances where nurses are the only health care practitioners available at a particular service point and are responsible for all activities taking place, including diagnosing, prescribing and dispensing. Where exceptions to the general rule discussed above occur, new laws and/or regulations have to be developed to make provision for and accommodate the needs of the situation. To accommodate special circumstances (which is the exception), section $22 \mathrm{~A}$ (12) of the Medicines and Related Substances Control Act (South Africa, 1965) makes provision for a concession whereby persons or institutions can apply for a permit to acquire, possess, use and supply medication. In addition, midwives have a regulation ( $R$ 32) related to Act 101, which makes provision for their special circumstances where deliveries have to be done at home and the midwife carries certain drugs with her to enable her to perform these services.

The "permit system" has been in place for non-pharmacists and institutions other than hospitals and pharmacies, to acquire, possess, use and supply medication (South Africa, 1965) for a number of years. This system has been fraught with problems mainly due to a lack of enabling legislation as well as a lack of clarity on exactly how the system works which resulted in the system being abused. For these reasons the Department of Health has placed a moratorium on the issuing of permits.

Section $22 \mathrm{~A}$ (12) does not provide the nurse with authorization to prescribe - this is provided for by Section 38A of the Nursing Act (South Africa, 1978). This section makes provision for the Director-General of Health or his delegate, to diagnose and prescribe medication for physical disorders.

Both these provisions are utilized in an effort to provide the nurse with a legal framework within which health care services could be delivered, but have many limitations and is not enabling at all (Bierman 1992: 49; Geyer, 1998:33).

\section{Purpose of this article}

The purpose of this article is to analyze the current legal framework for nurses/health practitioners to diagnose and prescribe medication in South Africa, in order to assess how enabling the legislation is for the practitioners involved, to identify the limitations in the current legal framework and to make recommendations for the way forward.

\section{Analysis of current legal situation}

The current South African legislation does not make clear and adequate provision for service delivery.

\section{Supreme law and subordinate law}

The Constitution of South Africa is supreme law and Parliament is the supreme legislature with regard to certain matters (South Africa, 1996). Parliament makes laws, which have to be in line with the Constitution. These laws provide the framework for the drafting of sub-ordinate legislation (i.e. regulations which details the practical implementation of the par- ent legislation, procedures to be followed and behaviour to be observed by persons to whom the parent legislation applies). Any sub-ordinate legislation in conflict with an Act of Parliament is invalid. If the Nursing Act therefore does not somewhere indicate that the nurse may diagnose and prescribe medication, the Director-General can not issue a regulation to authorize nurses to prescribe (Marais, 2001).

\section{The South African Constitution}

Section 22 of the Constitution (South Africa 1996) determines that every citizen has the right to choose their occupation or profession freely, but that such profession or occupation may be regulated by law. This determination was confirmed by two examples in case law:

- In the case of $S \vee L a w r e n c e, S \vee N$ Negal, $S \vee$ Solberg 1997 (4) SA 1176 (CC) the Constitutional Court found that although it was the individual's right to choose his trade, such participation must be in accordance with the law and it does not give anybody the right to break the law or to ignore laws having a rational basis (such as licensing and regulation of professions). The Court determined that the statutory provisions providing for selling of liquor to be regulated by licenses control -ling not only right to sell, but also where, when and what liquor may be sold, did not infringe on the right to engage "freely" in trade. The rationale for this deci -sion was that the excessive consumption of alcohol is harmful and some control over the sale of liquor is needed (Marais, 2001).

- In the case of Mistry v Interim National Medical and Dental Council 1998 (7) BCLR 880 (CC) it was confirmed that rights are never unconditional and with out obligations. The Constitution makes provision for the limitation of certain rights as indicated by this case. The professional in a regulated industry in fact con -sents to restrictions being placed upon him/her by the regulatory authorities (Marais, 2001).

The fundamental purpose of the Pharmacy Act and the Medicines and Related Substances Control Act is to:

regulate the manner in which scheduled substances are made available to members of the public. control the quality and supply of medicines generally. provide measures designed to:

- $\quad$ ensure proper standards and quality control and to maintain such stand -ards.

- $\quad$ protect the citizenry at large, as well as honest health professionals.

- $\quad$ regulate the establishment, maintenance and safeguarding of standards in the multiple health under takings. 


\section{Legislation pertaining to health professionals}

The legislation pertaining to the practice of the various health professionals indicate the rights and obligations of the practitioners involved (South Africa, 1974a; South Africa, 1974b; South Africa, 1978; South Africa, 1982). None of these Acts provides guidelines for the handling of medicine - that is done by the Medicines and Related Substances Control Act, Act 101 of 1965 (South Africa, 1965) which also makes provision for the Medicines Control Council (MCC) which oversees the handling of medicine.

The health professional acts provide certain rules for the various professionals in the health services. There are various overlaps in the scopes of practice of the different professional groups. To coordinate patient care necessitates the nurse moving into the gray areas of overlap of scopes of practice of the nurse, medical practitioner and other practitioners such as physiotherapists and dieticians, and pharmacists. If other members of the multi professional team are not available, the nurse must have the skills and discretionary ability to either do what needs to be done her/himself or to refer. This requires not only knowledge, skills and expertise, but also enabling legislation and regulations.

\section{Health Professions Act (No 56 of 1974)}

This Act determines that only persons registered under this Act may, for gain, diagnose and prescribe unless provided for in another Act. A list of such Acts is provided, which includes the Nursing Act (South Africa, 1974b).

The Health Professions Act does therefore not preclude the nurse and midwife from performing such professional services as they are entitled to perform by virtue of their professional status (Strauss \& Marais 1997:5). This includes diagnosing and prescribing medicine, provided that the Nursing Act makes legal provision for these activities.

\section{Pharmacy Act (No 53 of 1974)}

This Act determines that any person not registered as a pharmacist and who for gain performs any act specifically pertaining to the profession of a pharmacist, shall be guilty of an offence (South Africa, 1974a). Only a pharmacist may sell or supply medicine on the prescription of a medical practitioner.

An exception that is provided for in this Act, is the keeping of medicines and its supply to patients in hospitals or other institutions for the treatment of sick persons, under the direction of a medical practitioner and in accordance with the provisions of Act 101 of 1965 , by any registered or enrolled nurse (Section 29, South Africa, 1974a). This section also provides the legal authority to nurses in the medical service of the armed forces to handle and supply medication to members of the armed forces. Under this section a person can further be granted the authority to perform a service specifically pertaining to the scope of practice of a pharmacist on conditions determined by the Minister of Health.
The determinations in the Act that nurses working in institutions may only give medication to a patient on the prescription of a medical practitioner, means that the nurse may not give the patient any drugs, including unscheduled drugs such as Panado without the prescription of a medical practitioner. This limits the functioning of the nurse, because the medical practitioner in many occasions is only available for a limited time. The nurse should be legally empowered to give or prescribe at least the drugs that are available over the counter as the need arises.

Regulation R1158 (South African Pharmacy Council, 2000) defines the functions and scope of practice of the pharmacist. Regulation 3 contains the acts specially pertaining to the profession of a pharmacist and includes provision of pharmaceutical care (i.e. evaluation of patients' medicine related needs; dispensing; furnishing of information and advice; determining patient compliance with therapy and follow-up pharmacist initiated therapy); compounding, manipulation, preparation of medicine; and purchasing, acquiring, keeping, possessing, using, releasing, supplying or selling of medicine.

The scope of practice of a pharmacist (Regulation 4) consists of the acts specifically pertaining to the profession of a pharmacist, namely formulation; distribution; repackaging; initiation and conducting of pharmaceutical research; and the promotion of public health.

Should the pharmacist wish to provide a primary health care service, an additional course have to be completed and a Section 22A(12) permit applied for.

\section{Nursing Act (No 50 of 1978)}

The comment was made that the Nursing Act and its regulations are not clear at all about what nursing is and the scope of the nurse's practice - that it is too wide and non-specific (Marais, 2001). This statement opens up the whole debate about the nature of nursing - nursing can never be narrowed down to a list of tasks. In addition, the scope of practice has got to be wide to ensure that it makes provision for both the nurse in a high-tech environment in the hospital/clinic as well as a rural clinic where the nurse becomes responsible for all the functions normally performed by other practitioners (Geyer, 1998:33).

The Nursing Act determines that any person who is not registered as a nurse or enrolled as a nurse or a nursing auxiliary and who for gain performs any act pertaining to the profession of nursing shall be guilty of an offence (South Africa, 1978). The Minister may, on the recommendation of the Council, make regulations relating to various issues, including the scope of practice of registered or enrolled persons.

Authorization for certain nurses to diagnose and prescribe is made in terms of Section 38 (A) of The Nursing Act (South Africa, 1978). This provision only applies to a registered nurse employed by the Department of Health; Provincial Administration; Local Authority; or an Organization performing any health service designated by the Director-General: Health. The nurse is authorized in terms of this section by the Direc- 
tor-General: Health or his delegate such as the members of the Executive Council (MECs) of Provincial Departments of Health and the Medical Officer of Health at a Local Authority; or the medical practitioner in charge of a designated organization.

Designation of health services takes place within the framework of Section 38A of the Nursing Act (South Africa 1978). The Occupational Health services, mainly situated in the private sector, community based organizations and other private institutions providing a health service, will fall under this category of health services. In addition the Occupational Health and Safety Act (No 85 of 1993) makes it compulsory for employers with 20 or more employees in one workplace to provide for occupational health and safety. As with any other health service there are not enough medical practitioners available to perform these services and the services are performed by nurses. A recent development is that the Department of Health is in the process of designating companies with an occupational health service as a designated health service. This will enable the medical practitioner at this service to be delegated the authority to authorize nurses to diagnose and prescribe.

A nurse authorized in terms of this section may in the course of such employment and authority, physically examine a person; diagnose any physical defect, illness or deficiency in such person; keep prescribed medicines; prescribe, supply, and administer medicine on prescribed conditions; and promote family planning only when the services of a medical practitioner or pharmacist, are not available. Prescribing of medication without the required authorization, is a criminal offence and practitioners can be reported to the relevant Professional Council or the Department of Health (South Africa 1965; South Africa 1974 a; South Africa 1974 b; South Africa, 1978).

The limitations of section $38 \mathrm{~A}$ are the following:

The nurse in private practice cannot obtain the required legal authorization to prescribe medication unless some kind of employment relationship with a designated or -ganization exists. One example of such an employ -ment relationship that currently exists is the private nurse practitioner that has an agreement with a local authority or provincial department of health to deliver services (mainly immunization services) on behalf of the authority/department. In this agreement the au -thority/department provides the nurse with the re -quired medication free of charge on the condition that the nurse will not charge the patient for the medica -tion used and that she will provide the authority/de -partment with the statistics of the services delivered. The authorization to prescribe the medication is pro -vided by the local authority/ provincial health service as for any of their other employees. All midwives and community health care nurses are competent in the administration of immunization and the safekeeping of the relevant drugs, and no additional course will therefore be required for the authorization of the nurse/ midwife. The authority/service "pays" for services of the nurse by allowing the nurse to charge a consulta tion fee for professional services rendered. It is strongly recommended that these nurse practitioners obtain a written agreement with the particular authority/serv -ice.

- $\quad$ Provision is not made for midwives. The midwife in the service of the state must rely on a prescription by a medical practitioner for individual patients. This di -rectly affects the effective functioning of midwives in clinics and day hospitals (both public and private), where medical practitioners may not be available. Standing orders and protocols are made available for these nurses to administer, for example, Syntocinon and Vitamin $\mathrm{K}$.

- $\quad$ Nurses in the Defense Force, the Mines and Correc -tional Services are excluded as they are governed by other laws and are therefore not supervised by the $\mathrm{Di}$ -rector-General: Health.

- Provision is made only for "physical" assessment and diagnosing, thus excluding mental disorders.

- Authorisation can only be granted in the absence of a doctor or pharmacist. This is in contradiction to the health policy of the Government.

- There are no guidelines or regulations to direct the process of authorizing nurses to diagnose and prescribe. Furthermore it is not clear how many nurses are au -thorized to diagnose and prescribe or where these nurses are.

Removal of Section 38A from the Nursing Act (South Africa 1978) will prove to be disastrous because it will remove the only legal determination according to which at least some of our nurses can be authorized to diagnose and prescribe. The Nursing Act must, however, be amended to make adequate provision for nurses and midwives to diagnose and prescribe treatment, whether these practitioners are employed in private or public health services. The authorization process must be amended so that the service provider has to prove the need to have nurses authorized to prescribe medication. It would then be possible for a clinic where there is one medical practitioner, to have a number of nurses authorized to diagnose and prescribe medication, as the one medical practitioner cannot see all the patients visiting the clinic and thus there is a proven need to have additional prescribing practitioners.

Registers have to be initiated and kept current by the Statutory Councils to indicate who have been authorized to prescribe and/or dispense medication. Authorization should be based on specifications/ regulations to ensure that standards are set and uniformly applied. The Statutory Councils must identify the skills, training and accreditation of programmes required to enable the professions to deliver the required services and these should be used as the basis for the authorization of nurses. Employers of nurses who are responsible for delivering a health service that require nurses to be authorized (such as occupational health services), must apply to the Director-General of Health to have the service designated as a health service.

The Regulations relating to the Scope of Practice of persons 
who are registered or enrolled under the Nursing Act (South Africa 1978) determines the legal framework for practitioners practicing in this field. The Scope of practice of a registered nurse shall entail the following acts or procedures relating to diagnosing and prescribing (South African Nursing Council, 1984):

(a) the diagnosing of a health need and the prescribing, provision and execution of a nursing regimen to meet the need of a patient or, where necessary, referral to a registered person;

(b) the execution of a program of treatment or medication prescribed by a registered person for a patient;

(c) the treatment and care of and the administration of medicine to a patient, including the monitoring of the patient's vital signs and of his reaction to disease con -ditions, trauma, stress, anxiety, medication and treat -ment;

(d) the prevention of disease and promotion of health and family planning by teaching to and counseling with individuals and groups of persons.

The use and definition of the term 'nursing and midwifery regimen' remains the biggest limiting factor in the legal authorization of nurses/midwives to diagnose and prescribe medication (Geyer, 1998: 28).

The limitations of these regulations can be addręssed as follows:

- The scope should be wide and linked to the outcomes of the programme completed by the practitioner. It should make provision for both the nurse in the hightech environment as well as the rural areas where the nurse becomes responsible for many activities traditionally performed by other professionals.

- The term regimen must be redefined to make provision for all kinds of prescribing efforts that the nurse may be required to do.

Regulation 2418 pertaining to the keeping, supply, administering or prescribing of medicine by registered nurses restricts the nurse/midwife to schedule $1-4$ medication.

The exclusion of the nurse from prescribing and keeping higher scheduled drugs, is a big stumbling block for the psychiatric nurse and the nurse in palliative care.

The limitation in terms of scheduled medication that nurses may prescribe and issue to the patient limits the ability of the nurse to deliver a comprehensive health service. This regulation should be withdrawn as it is in contradiction with the determination of the Medicines and Related Substances Amendment Act (South Africa 1997) which not only includes the nurse as a practitioner that may handle and prescribe drugs, but also makes provision for the nurse to have access to schedule 1 - 6 drugs. The moratorium on the implementation of the Amendment Act (South Africa, 1997) has been lifted and it will become operational shortly.

Education and training of practitioners to diagnose, prescribe and, in some instances, dispense medication is crucial. The nurse practitioner always remains accountable for all her/ his acts and or omissions and they must be adequately pre- pared to ensure the competency required to deliver primary health care services (Muller, 1996: 76; Verschoor, Fick, Jansen, \& Viljoen, 1997: 11). Support systems and adequate facilities must be put in place to enable the nurse to deliver a comprehensive health service of high quality. Regulations and directives for relevant training programmes are in place. The emphasis of the Diploma In Clinical Nursing Science, Health Assessment, Treatment And Care (Primary Clinical Care) is to develop the clinical competencies of the primary clinical practitioner (nurse practitioner) to render a comprehensive service in the clinics (South African Nursing Council, 1993).

Even though a nurse has successfully completed a course in clinical skills (South African Nursing Council, 1985 b), she does not have the right to be authorized to prescribe, or to obtain a section $22 \mathrm{~A}$ (12) permit. A permit is only for special circumstances and remains a concession (South Africa, 1965).

\section{The Medicines and Related Substances Control Act (101 of 1965)}

Section 22A (12) of Act 101 determines that the DirectorGeneral may issue a permit (South Africa, 1965):

- To any person or organization performing a health service.

- $\quad$ Authorizing them to acquire; possess; use; and supply medication.

- For specified Schedule 1-4 substances only.

- Subject to such conditions as the Director-General may determine.

It must be noted that the section $22 \mathrm{~A}(12)$ permit does not allow for the practitioner:

- $\quad$ To sell medicine - only to supply it.

- $\quad$ For access to all medicines, but only for access to cer -tain schedule $1-4$ drugs included in the Essential Drugs List (EDL) of the Government.

- Authorisation to prescribe medication - this provision should be made in the professional acts governing the practitioner's practice. Section 38 A only makes provision for the nurse to diagnose and prescribe and no other practitioner.

Irrespective of the objective of the individual or organization to provide services and the needs of the community for such services, there is no obligation on the Department to issue permits. If the Department of Health issues permits to persons who do not qualify under the current legislation, they may be held jointly liable if any problem should arise (South Africa, 1965). The Department has indicated that the permit application procedures will be re-evaluated to ensure that it is in line with the current legislation. These will be available from the Department of Health after March 2001.

Any health care practitioner, who keeps and supplies scheduled medication to clients without the required $22 \mathrm{~A}(12)$ permit, is guilty of an offence. Suppliers selling scheduled medication to a health care professional that do not have the required legal permit are guilty of an offence (South Africa, 1965). 
Step-down facilities are a new type of health care facility, which are increasing in number. There are no national regulations yet to govern these institutions in terms of Section 44 of the Health Act (South Africa, 1977). One of the main concerns is the handling of medication in these institutions where there usually is no permit to acquire, keep, use and supply medication. Within the above mentioned legal framework, it is advisable that the client be discharged from the hospital with a T.T.O. (prescribed medication to take home) and kept by the client who becomes responsible for taking his own medication in the step-down facility. The ideal is that regulations be developed for these institutions to ensure that they meet certain minimum requirements for licensing. Some provincial health authorities are already accrediting these institutions.

The moratorium on the implementation of the 1997 amendment to Act 101 has been set aside and new general regulations has been published for public comment (South Africa, 1997). This amendment act makes legal provision for the nurse to have access to certain schedule $1-6$ medications. These regulations also make a distinction between systems to authorize to prescribe and authorization to dispense medication. In future authorization to diagnose and prescribe will be done by the professional councils and licensing to compound and dispense medication by the Director-General of Health on the successful completion of a course approved by the Pharmacy Council. The amended regulations will hopefully be published before the end of 2001 .

\section{The Right to Sell Schedule 2 - 5 Medicines}

Based on the abovementioned discussion, the right to sell scheduled medicines can be summarized as follows (South Africa, 1965; South Africa 1974 a; South Africa 1974 b):

(a) The General Rule [Sec 22a (1)] pharmacist; pharmacist intern and the pharmacist assistant under supervision.

(b) The exceptions are medical practitioners, dentists, or veterinary surgeon for their own patients; employee of a manufacturer or wholesaler for the purpose of sale to a medical practitioner, pharmacist, dentist or vet -erinary surgeon; pharmacists for Schedule 5,6 \& 7 without a script in an emergency; and veterinary assistants on the prescription of a veterinary surgeon.

The permit in terms the special dispensation of Section $22 \mathrm{~A}$ (12) does not make provision for selling medication.

\section{Conclusion}

The complexity of the situation, mainly due to a lack of enabling legislation and rapidly changing health service delivery needs, is clear. All health care practitioners and institutions have to comply with the current legislation and steps have to be taken to do so as a matter of urgency. The legislative framework, and specifically the Nursing Act and its regulations, has to be changed to enable nurses to deliver the services. In the meantime, all practitioners have to comply with the current legislation. Strategies have to be developed in the long term to ensure enabling legislation for nurses and midwives in South Africa. Lobby groups must get together to strategize for empowering legislation for nurses and midwives to deliver a comprehensive health service.

\section{References}

BIERMAN, JK 1992: Legal limitations in primary health care nursing practice. Johannesburg: Rand Afrikaans University. (Unpublished M-Cur dissertation).

DEPARTMENT OF HEALTH 1996: Restructuring the National Health Services for universal Primary Health Care. Official Policy Document issued by the National Department of Health. Pretoria: Department of Health.

GEYER, N 1998: Legal limitations for nurse prescribers in primary health care. Curationis. 21(4): 28 - 33. December 1998.

KLUGE, J 1998: Nurses rendering a primary health care service in private sector. (Road show: Private Nurse Practitioner Workshop, CSIR Conference Center, Pretoria. 3 November 1998).

MARAIS, P 2001: Clarifying the legal framework. (Workshop held at Caesar's, Gauteng: organized by the Department of Health, 15 January 2001).

MULLER, ME 1996: Nursing Dynamics (Second edition). KwaZulu-Natal: Heinemann.

PILLAY, Y 2001: Interview with the Department of Health regarding the designation of health services.

SOUTH AFRICA 1965: Medicines and Related Substances Act (Act 101 of 1965, as amended). Pretoria: Government Printer.

SOUTH AFRICA 1974a: Pharmacy Act (Act No53 of 1974 as amended). Pretoria: Government Printer.

SOUTH AFRICA 1974 b: Health Professions Act (Act 56 of 1974, as amended). Pretoria: Government Printer.

SOUTH AFRICA 1977: Health Act (Act 63 of 1977, as amended). Pretoria: Government Printer.

SOUTH AFRICA 1996: Constitution of the Republic of South Africa Act (Act 108 of 1996). Pretoria: Government Printer.

SOUTH AFRICA 1978: Nursing Act (Act No 50 of 1978, as amended). Pretoria: Government Printer.

SOUTH AFRICA 1982: Chiropractors, Homeopaths and Allied Health Service Professions Act (Act 63 of 1982, as amended). Pretoria: Government Printer.

SOUTH AFRICA 1996: Constitution of the Republic of South Africa (Act 108 of 1996). Pretoria: Government Printer. 
SOUTH AFRICA 1997: Medicines and Related Substances Amendment Act (Act 90 of 1997). Pretoria: Government Printer.

SOUTH AFRICAN NURSING COUNCIL 1984: R 2598, as amended. Regulations relating to the scope of practice of persons registered or enrolled under the Nursing Act, 1978. Pretoria: SANC.

SOUTH AFRICAN NURSING COUNCIL 1985a: Directive for the diploma in Clinical Nursing Science, Health Assessment, Treatment and Care. Pretoria: SANC.

SOUTH AFRICAN NURSING COUNCIL 1985 b: Directive for the Diploma in Clinical Nursing Science, Health Assessment, Treatment and Care. Pretoria: SA Nursing Council.

SOUTH AFRICAN NURSING COUNCIL 1993: Teaching guide for a course in Clinical Nursing Science leading to registration of an additional qualification. Pretoria: SA Nursing Council.

SOUTH AFRICAN PHARMACY COUNCIL 2000: Regulation R1158 Government Gazette No. 21754: 20 November 2000. Pretoria: Pharmacy Council.

STRAUSS, SA \& MARAIS 2000: Medical Jurisprudence. Study guide 2 for MJU $400-K$. Division B: Ius medicum. Department of Criminal \& Procedural Law, Pretoria: UNISA.

SUBEDAR, H 2001: Prescribing by nurse practitioners (Paper delivered at the Clinical Nurse Practitioner 9-12 May 2001, SA Technikon Conference Center, Johannesburg).

VERSCHOOR, T; FICK, GH; JANSEN, R-M \& VILJOEN, DJ 1997: Nursing \& the law. Cape Town: Juta \& $\mathrm{Co}$. 